\title{
Determination of the True Specific Gravity of Coke
}

\author{
By Harold J. Rose \\ The Koppers Company Laboratories, Mellon Instrute of Industrial Research, Pittseurgh, Pa.
}

Some of the methods in use for the determination of the true specific gravity of coke vary in important respects. This paper is presented to show the urgent need of an official method for this determination.

Data are given to show the effect of the degree of pulverization of the sample, the nature of the liquid used, the time of boiling and standing, and the effect of partial vacuum.

When 60-mesh coke samples were pulverized to pass a 200-mesh sieve, the true specific gravity was found to increase by as much as 12.7 per cent. The greatest increase was noted in the case of cokes which had been made below $800^{\circ} \mathrm{C}$.

When the effect caused by a change of liquids was examined, benzene was found to give much the lowest results. Figures obtained by using benzene were as much as 8.1 per cent lower than those obtained by using water.

The true specific gravity of coke is usually determined for the purpose of calculating the porosity of the sample in question. The discrepancies mentioned above, when expressed in terms of porosity. amount to as much as 30 to 50 per cent of the total variation in porosity which will be found in different blast-furnace cokes.

$V$ ariations of the time of boiling and standing in the wetting liquid, and the use of partial vacuum during boiling, also produced discrepancies, although these were considerably smaller than those mentioned above.

It is for this reason, presumably, that many methods require the use of finely powdered coke, the degree of fineness when specified ranging from 40 to 80 mesh. It has been found in this laboratory that a very distinct increase in the true specific gravity is obtained when the pulverization is carried to a still greater extent. No comparisons have been made with methods involving the use of large coke pieces, as this practice does not seem defensible from any standpoint.

Experimental Data on Influence of FinenessTable I gives data concerning the effect of fineness of pulverization on the true specific gravity figure. The sample used consisted of a mixture of the middle thirds (the "cauliflower" and center of oven ends being rejected) of two full-sized pieces of by-product coke made from 100 per cent high volatile West Virginia coal.

The material was first crushed to 20 -mesh size by means of steel rolls. $500 \mathrm{~g}$. were then placed in an Abbé pebble mill-a porcelain jar 7 in. in inside diameter, and 7 in. deep, half filled with quartz pebbles. The pebble mill made 54 r. p. m. $100 \mathrm{~g}$. portions were removed after the following intervals: 1 hr. 15 min., 2 hrs. 15 min., 5 hrs. 15 min. The remaining $200 \mathrm{~g}$. were made into a thin paste with distilled water and were pebble-milled for another $24 \mathrm{hrs}$. Another sample was prepared by repeatedly passing a part of the original 20-mesh sample through steel rolls, and sieving. This process was continued until all had passed through a 60 -mesh sieve.

A portion of each sample was dry-sieved in order to obtain an approximate idea of its fineness. Ash determinations were also made in duplicate, to find out whether or not mineral impurity was introduced during the prolonged grinding.

The determinations in Table I, and all others reported in this paper, were made in the following manner, except where otherwise noted.

Method UseD-A 10-g. sample of coke which had been dried at $105^{\circ} \mathrm{C}$. was introduced into a 50 -cc. volumetric flask provided with a ground-glass stopper. The flask was filled about one-third full with C. P. benzene, and the mixture gently boiled on an electric hotplate for one-half hour. The flask was cooled, filled approximately to the mark with benzene, and placed for at least $15 \mathrm{~min}$. in a water bath kept at exactly $25^{\circ} \mathrm{C}$. The meniscus was adjusted to the mark at that temperature, and the flask was stoppered, wiped dry, and weighed.
${ }^{1}$ Received March 28, 1922. Presented before the Division of Industria and Engineering Chemistry at the 63rd Meeting of the American Chemical Society, Birmingham, Ala., April 3 to $7,1922$. 
The calculations were made as follows:

Let $\mathrm{S}=$ weight of coke sample

$\mathrm{B}=$ weight of flask filled with benzene

$\mathrm{D}=$ weight of flask, coke, and benzene (after boiling). Then

True specific gravity $=\frac{S}{B+S-\bar{D}} \times$ sp. gr. benzene

All results given in this paper have been calculated to true specific gravity at $25^{\circ} \mathrm{C}$., referred to water at $15.5^{\circ}$. $\left(15.5^{\circ} \mathrm{C}\right.$. is the usual coke plant standard and approximates $60^{\circ} \mathrm{F}$.)

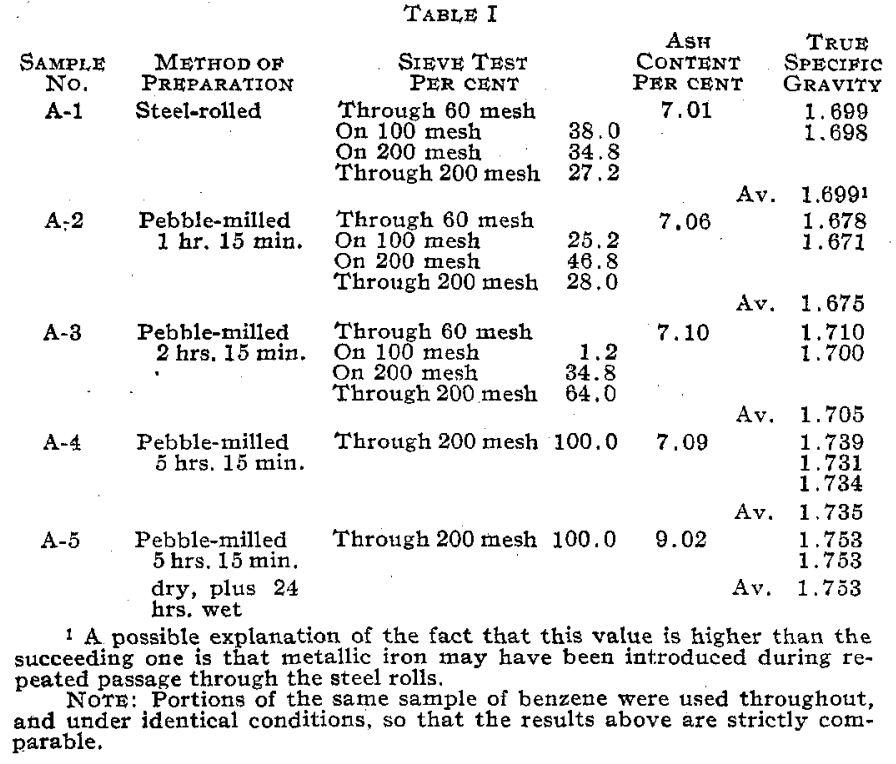

COMMENTS on TABLE I: (1) Since the wet-pebble milling of coke for 24 hrs. resulted in a 2 per cent increase in ash content, this treatment would not be permissible. The rise in the true specific gravity figure after wet grinding is 0.018 . The calculated effect of the introduction of 1.93 per cent quartz happens to be exactly 0.018 . Thus, in this instance, there appears to be no real gain in the true specific gravity when 200 -mesh coke is pulverized still finer.

(2) Dry-pebble milling of a large sample for as long as $5 \mathrm{hrs}$. did not introduce more than a trace of mineral impurity.

(3) The maximum and minimum acceptable figures obtained above show a variation of 0.060 , which a mounts to 3.4 per cent.

From an examination of the results of other tests made at the same time, it was soon found that the effect of fineness of pulverization was still greater in the case of cokes made at comparatively low temperatures (below $800^{\circ} \mathrm{C}$.). To secure information on this point, several series of cokes were made in the laboratory at various temperatures. In making these cokes a standard practice was followed, which proved to yield coke most nearly comparable to that obtained in fullscale operation.

The cokes obtained were crushed to 20-mesh size and divided into two portions. One portion was crushed in a diamond steel mortar to just pass 60 mesh. The other half

\begin{tabular}{|c|c|c|c|c|c|}
\hline $\begin{array}{c}\text { SAMPL } \\
\text { No. }\end{array}$ & DESCRIPTION & $\begin{array}{l}\text { TaBLE } \\
\text { Temp. of } \\
\text { Coking } \\
\circ \mathrm{C} .\end{array}$ & $\begin{array}{l}\text { True } \\
\text { of } \\
60 \text { Mesh }\end{array}$ & $\begin{array}{l}\text { Sp. Gr. } \\
\text { Coke } \\
200 \text { Mesh }\end{array}$ & $\begin{array}{l}\text { Increase of Sp. } \\
\text { Gr. Dute to } \\
\text { Pulverization }\end{array}$ \\
\hline B & $\begin{array}{l}\text { Laboratory coke made } \\
\text { from 100 per cent } \\
\text { Pittsburgh Seam, high } \\
\text { volatile coal }\end{array}$ & $\begin{array}{l}700 \\
750 \\
850 \\
950\end{array}$ & $\begin{array}{l}1.558 \\
1.633 \\
1.742 \\
\cdots\end{array}$ & $\begin{array}{l}1.702 \\
1.798 \\
1.817 \\
1.823\end{array}$ & $\begin{array}{l}0.144 \\
0.165 \\
0.075 \\
\cdots\end{array}$ \\
\hline c & $\begin{array}{l}\text { Same coke as } B \text {, except } \\
\text { that when made the } \\
\text { heating was continued } \\
\text { for } 2 \text { hrs. longer }\end{array}$ & $\begin{array}{l}700 \\
750 \\
850 \\
950\end{array}$ & $\begin{array}{l}1.639 \\
1.693 \\
1.815 \\
1.842\end{array}$ & $\begin{array}{l}1.723 \\
1.800 \\
1.863 \\
1.886\end{array}$ & $\begin{array}{l}0.084 \\
0.107 \\
0.048 \\
0.044\end{array}$ \\
\hline$D$ & $\begin{array}{l}\text { Laboratory coke made } \\
\text { from a mixture of } 80 \\
\text { per cent Pittsburgh } \\
\text { Seam coal and } 20 \\
\text { per cent low volatile } \\
\text { material }\end{array}$ & $\begin{array}{l}750 \\
850 \\
950\end{array}$ & $\begin{array}{l}1.547 \\
1.677 \\
1.840\end{array}$ & $\begin{array}{l}1.743 \\
1.735 \\
1.846\end{array}$ & $\begin{array}{l}0.196 \\
0.058 \\
0.006\end{array}$ \\
\hline
\end{tabular}

was pulverized for about $3 \mathrm{hrs}$. in an Abbe pebble mill, until it readily passed through a 200 -mesh screen.

Table II gives the results of tests on these cokes. The determinations were carried out in the same way as described for Table I.

Comments on TAble II: (1) The effect of fineness of pulverization is greatest in the case of cokes made in the laboratory at $700^{\circ}$ and $750^{\circ} \mathrm{C}$., the discrepancies at these temperatures averaging 8.6 per cent, and reaching a maximum of 12.7 per cent.

(2) When calculated to porosity

$$
\text { (Porosity }=100-\frac{100 \times \text { apparent sp.gr. }}{\text { true sp. gr. }} \text { ) }
$$

assuming for convenience an apparent specific gravity of 0.900 , these discrepancies average 4.5 per cent with a maximum of 6.6 per cent.

(3) Since the actual range of porosity of different blast furnace cokes is only about 15 per cent (from 42 to 57 when determined by a particular method), as small a matter as the degree of fineness of pulverization of a particular sample may make a difference 40 to 50 per cent as great as the variation to be expected between the densest and most porous cokes in use. It is clear that the degree of pulverization must be carefully regulated.

\section{Variations Due to the Liguids Used}

A series of determinations was made, using water, benzene, carbon tetrachloride, and carbon bisulfide. The organic liquids had been obtained from standard chemical supply houses, and were labeled "pure" or "C. P." The specific gravity of these liquids was determined by pycnometer, under the same conditions as were used for the tests with coke. Except for the variation in liquids used, the determinations of Table III were made according to the method immediately preceding Table I.

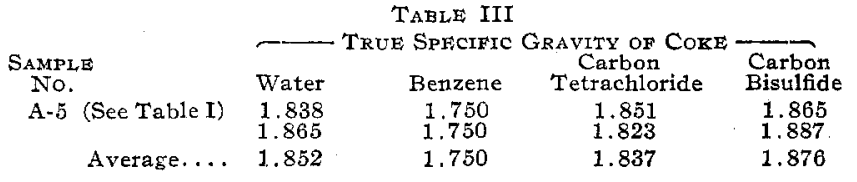

The low figure for true specific gravity obtained by using benzene will at once be noted. While the agreement between individuals of duplicate determinations is not especially good in some of these cases, the low results obtained with benzene are much too large to be ascribed to experimental error. The variation between results obtained by benzene and water in the instance above is 0.102 . Several more determinations were made to further compare the results obtained by using benzene and water.

\begin{tabular}{|c|c|c|c|c|}
\hline \multirow{4}{*}{$\begin{array}{c}\text { SAMPLE } \\
\text { No. } \\
\text { A-1 }\end{array}$} & TABI & \multirow{2}{*}{\multicolumn{2}{|c|}{$\begin{array}{r}\text { TRUE SPECIFIC GRaviTY OF CoKE } \\
\text { Lowering of True } \\
\text { Water Benzene } \begin{array}{l}\text { Specific Gravity } \\
\text { Due to Benzene }\end{array}\end{array}$}} & \multirow{2}{*}{$\begin{array}{l}\text { Gravity OF Coke } \\
\text { Lowering of True } \\
\text { Specific Gravity } \\
\text { Due to Benzene }\end{array}$} \\
\hline & DESCRIPTION & & & \\
\hline & (See Table I) & $\begin{array}{r}1.870 \\
\cdot \quad 1.828\end{array}$ & $\begin{array}{l}1.699 \\
1.698\end{array}$ & \\
\hline & Average. ..... & $1.849^{1}$ & 1.699 & 0.150 \\
\hline \multirow[t]{2}{*}{ A-3 } & (See Table I) & $\begin{array}{l}1.876 \\
1.869\end{array}$ & $\begin{array}{l}1.753 \\
1.753\end{array}$ & \\
\hline & Average..... & $1.873^{1}$ & 1.753 & 0.120 \\
\hline \multirow[t]{2}{*}{$\mathrm{E}$} & $\begin{array}{l}\text { 200-mesh sample "Cauli- } \\
\text { fower" } 1 / 3 \text { of two pieces of } \\
\text { coke made from } 100 \text { per } \\
\text { cent high vol. W. Va. coal }\end{array}$ & $\begin{array}{l}1.922 \\
1.901\end{array}$ & $\begin{array}{l}1.809 \\
1.804\end{array}$ & \\
\hline & Average...... & $1.912^{1}$ & 1.807 & 0.105 \\
\hline $\mathbf{F}$ & $\begin{array}{l}\text { By-product coke from mixture } \\
\text { of three Colorado coals }\end{array}$ & $\begin{array}{l}1.965 \\
1.924\end{array}$ & $\begin{array}{l}1.907 \\
1.934\end{array}$ & \\
\hline 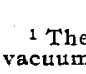 & $\begin{array}{l}\text { Average. ..... } \\
\text { thions were made }\end{array}$ & $\begin{array}{c}1.945 \\
\text { by boilin }\end{array}$ & $\begin{array}{l}1.920 \\
\text { or } 21 / 2\end{array}$ & $\begin{array}{l}0.025 \\
\text { under moderate }\end{array}$ \\
\hline
\end{tabular}

The largest lowering of specific gravity due to the use of benzene that is recorded in Table IV, is 0.150 , or 8.1 per cent.

When calculated to "porosity," as explained in the com'ments on Table II, this discrepancy will be about 30 per cent as great as the total variation in porosity of the most widely different blast-furnace cokes. 